\title{
PI3K/mTOR-dependent signaling pathway as a possible regulator of processing body assembly
}

\author{
D. O. Gudkova', , G. G. Panasyuk ${ }^{1}$, I. O. Nemazanyy ${ }^{1}$, V. V. Filonenko ${ }^{1}$ \\ ${ }^{1}$ Institute of Molecular Biology and Genetics, NAS of Ukraine \\ 150, Akademika Zabolotnoho Str., Kyiv, Ukraine, 03680 \\ ${ }^{2}$ Taras Shevchenko Kyiv National University \\ 64, Volodymyrska Str., Kyiv, Ukraine, 01033 \\ filonenko@imbg.org.ua
}

\begin{abstract}
Aim. To study the role of PI3K/mTOR signaling pathway in regulation of processing body (PB) assembly. Methods. During this study we employed cell imaging technique and Western blot analysis. Results. It was shown that treatment of cells with the specific inhibitors of PI3K/mTOR pathway leads to changes of PBs ' number and size within cells as well as proteasomal degradation of their scaffold protein RCD-8. Conclusions. We speculate that mTOR/PI3K pathway may regulate in part the dynamic of $P B$ formation in the cell by affecting the stability of RCD-8 protein and therefore controle $m R N A$ metabolism.
\end{abstract}

Keywords: processing bodies, immunocytochemistry, mRNA degradation, mTOR, signaling pathway.

Introduction. It is well known that phosphorylation of S6Ks and 4E-BPs by mTOR regulates the rate of translation initiation in response to diverse extracellular stimuli, such as growth factors, mitogenes and nutrients [1-3]. According to the model of steric competition for binding of protein complexes to the cap on mRNA it has been proposed that initial formation of the cap-de-pendent translation initiation complex may affect in part the total rate of mRNA translation via preventing the decapping of these targets. However there is no evidence that PI $3 \mathrm{~K} / \mathrm{mTOR}$ signaling pathway may directly affect the activity of decaping machinery and as a consequence RNA degradation that occurs in specific sites within the cell. Recently it was shown that non translating mRNAs can be accumulated in cytoplasmic RNP granules [4-8]. At present the best-characterized mRNP granules in the somatic cell cytoplasm are processing bodies (PBs) and stress granules (SGs) [5]. They are ubiquitotus highly dynamic membraneless structures, which contain pool of untranslated mRNAs. PBs contain enzymes and their co-activators for mRNA degrada-

(C) Institute of Molecular Biology and Genetics, NAS of Ukraine, 2011 tion and translational repression $[6,8]$, whereas SGs represent mRNPs with number of proteins involved in the translation initiation including $40 \mathrm{~S}$ ribosomal subunit $[4,5]$. RCD-8 is known as one of scaffold proteins of PBs, which is crucial for their assembly $[9,10]$.

Previously, we have generated mouse polyclonal antibodies against bacterially expressed recombinant $\mathrm{N}$ terminal region of RCD-8 [11]. The specificity of antibodies was analyzed by immunofluorescence approach. We have detected some specific foci in the cytoplasm of HEK293 cells. To check whether these structures correspond to PBs or SGs (another related kind of mRNP granules) we overexpressed the markers of PBs and SGs fused with fluorescent proteins in HEK293 cells. Using IF microscopy we confirmed the specificity of purified antibodies with respect to $\mathrm{PB}$.

In view of the absence of published data regarding regulation of $\mathrm{PB}$ assembly in mammalian cells by signaling pathways we decided to investigate the role of known mTOR/PI3K signaling pathway inhibitors in dynamic of $\mathrm{PB}$ formation.

Materials and methods. Plasmids and antibodies. Rabbit anti-RCD-8 antibodies were obtained from «Be- 
thyl Laboratories» (USA). Mouse anti-RCD-8 antibodies were described previously [11]. Anti-mouse FITCconjugated antibodies were from Jackson ImmunoResearch Laboratories. Anti-mouse Texas Red-conjugated antibodies were from «Invitrogen» (USA). Antiphospho-p70 S6K1 (Thr 389), phospho-4E-BPs and $\beta$ actin antibodies were obtained from «Millipore» (USA). Secondary HRP-labelled anti-mouse and anti-rabbit antibodies were from «Cell Signaling» (USA).

Cell culture and immunocytochemistry. HEK293 cells were obtained from the American Type Culture Collection and maintained in DMEM supplemented with $10 \%$ fetal bovine serum («HyClone», UK), penicillin $(200 \mathrm{U} / \mathrm{ml})$ and streptomycin $(200 \mathrm{mg} / \mathrm{ml})$. To induce PB assembly/disassembly HEK293 cells were exposed to sodium arsenite (III) $(0.5 \mathrm{mM})$, cycloheximide (CHX, $50 \mathrm{mg} / \mathrm{ml})$, LY294008 $(50 \mu \mathrm{M})$, rapamycin $(200 \mathrm{nM})$ and 2-deoxyglucose (2-DG, $25 \mathrm{mM})$ for $30 \mathrm{~min}$ at $37^{\circ} \mathrm{C}$. All reagents were obtained from «Sigma» (USA). For inhibition of proteasomal degradation MG132 («Merck», Germany) was added to cells for $6 \mathrm{~h}$ at final concentration $10 \mu \mathrm{M}$. For immunofluorescent staining HEK293 cells were grown in tissue culture chambers («Nunc», Denmark), fixed with $3.7 \%$ paraformaldehyde in PBS, and permeabilized with PBS-T $(0.2 \%$ Tween-20) three times for $5 \mathrm{~min}$. Unspecific binding was blocked by $45 \mathrm{~min}$ incubation with $5 \%$ FBS diluted in PBS-T. Afterwards staining with primary and secondary antisera was performed as described previously $[12,13]$.

Cell nuclei were stained with Hoechst 33258 dye («Invitrogen», USA). Fluorescently labelled cells were analyzed with a Zeiss LSM Meta 510 confocal microscope, and the images were edited using the LSM510 image browser software. All pictures were acquired and processed using the same settings.

SDS-PAGE, Western blotting. HEK293 cell protein extracts were resolved in SDS-polyacrylamide gels and transferred to PVDF membrane («Millipore»). Membranes were incubated in blocking solution and probed with primary rabbit antibodies, diluted in TBST $(25 \mathrm{mM}$ Tris- $\mathrm{HCl}(\mathrm{pH} 7.4), 0.8 \% \mathrm{NaCl}, 0.02 \% \mathrm{KCl}$, and $0.05 \%$ Tween). After washing three times with TBST the membrane was incubated with HRP-conjugated goat antirabbit IgG («Promega», USA). Finally, the membrane was developed using an ECL kit («GE Healthcare», UK) and then exposed to Agfa X-ray film.
Results and discussion. In the beginning we looked for possible changes in PBs' number and/or size under different experimental conditions. For this purpose we treated cells with signal transduction and metabolic inhibitors, targeting the mTOR/PI3K pathway, namely LY294002 (an inhibitor of PI-3 kinase), rapamycin (an inhibitor of mTORC1) and 2-DG (an inhibitor of glycolysis, which activates AMPK and therefore leads to mTORC1 inactivation) [14]. After the treatment for 30 min cells were stained with anti-RCD- 8 affinity purified antibodies. As shown on Fig. 1 (see inset) we observed that treatment of HEK293 cells with LY294002 and 2-DG leads to the enrichment of PBs within the cytoplasm. Moreover, we could observe changes not only in number of PBs but in their size as well. Notably, observed changes differed from typical induction of PBs with sodium arsenite (a known inductor of PBs assembly) $[4,5]$. Thus, treatment with LY294002 resulted in the production of predominantly small processing bodies in contrast to 2-DG treatment, which led to the appearance of PBs similary to the effect of arsenite. It is known that PB assembly occurs through formation of small particles with further fusion into the larger PBs [4]. We believe that LY294002 targeting PI3K signaling initiates formation of small PBs but their fusion may require additional impacts. Unexpectedly treatment of cells with direct mTOR inhibitor rapamycin (which inhibits only mTORC 1 complex, but not mTORC2) (Fig. 1, $b$, see inset) led to the opposite effect, namely to the disappearance of PBs, like treatment with known inhibitor of translation - CHX [4, 5] (Fig. 1, e, see inset). This finding is very intriguing, because treatment with LY294002 indirectly inhibits the activity of mTOR kinase in both mTORC1 and mTORC2 complexes in mammalian cells.

These data indicate that the inhibition of mTOR-kinase via different mechanisms and in different complexes has led to opposite effects in respect to PB assembly. In addition such effect may be facilitated by additional mTOR substrates other than S6K1 and 4E-BPs since the mTOR dependent phosphorylation of both of them is down regulated by LY294002 and rapamycin (Fig. 2, A).

Despite the similar effect on PB disassembly induced by CHX and rapamycin, we show that they exhibit different effects on mTOR kinase substrates - S6K and 4E-BPs. As it is demonstrated on Fig. 2, $A$, in contrast to rapamycin $\mathrm{CHX}$ treatment elevates $\mathrm{S} 6 \mathrm{~K} 1$ phos- 

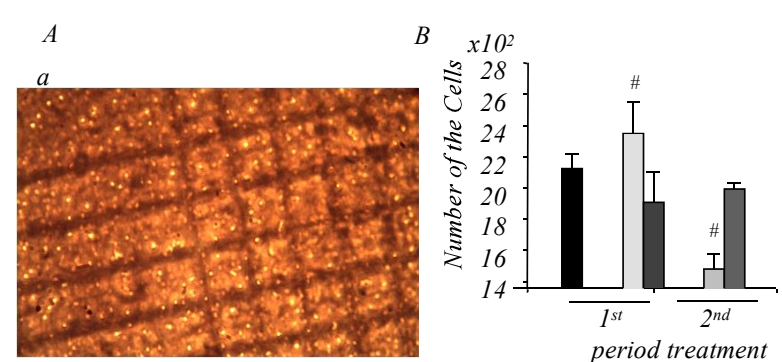

$b$

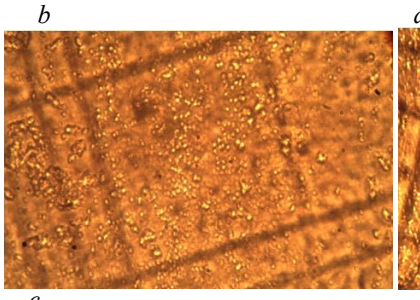

$d$
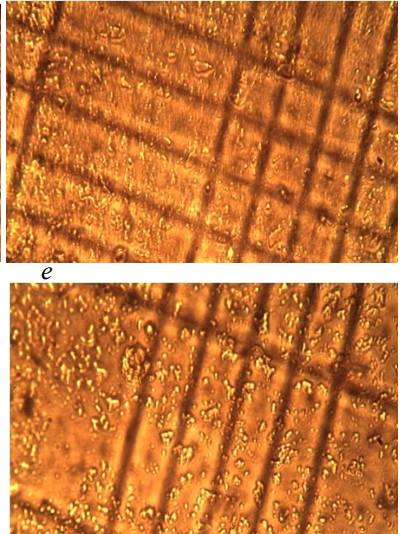

Fig. 2. The influence of Allopurinol on the cell number at day $12^{\text {th }}$. magnification $60 \times 1.25 \times 20$. The first group of the cells was treated during the entire period of the culturing, from day $1^{\text {st }}$ until the day $12^{\text {th }}(b, c)$, whereas the second group was treated during the second period, which was starting from day $6^{\text {th }}$ until day $12^{\text {th }}(d, e)$. Also, it was used t-student test to calculate the significance of the results. Results were considered significant, if $\mathrm{p}<0.05$. The results related with the low concentration of Allopurinol in comparison with each other and Control $(a)$ were statistically significant

Figure to article D. O. Gudkova et al.
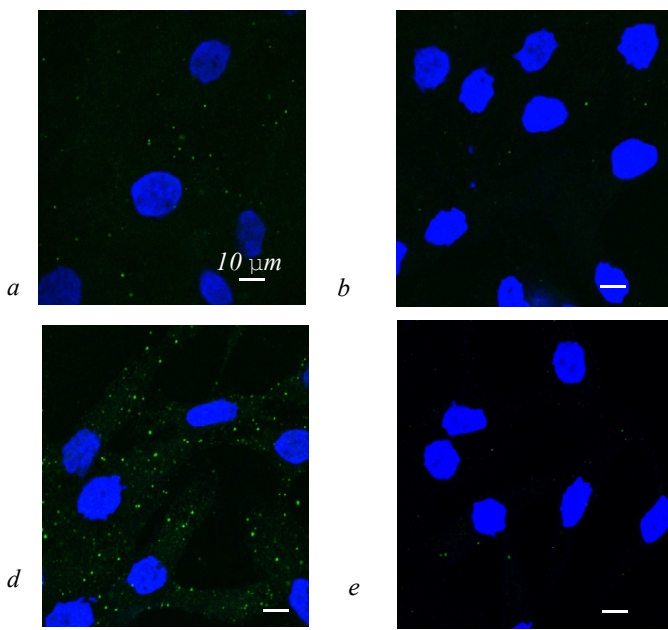
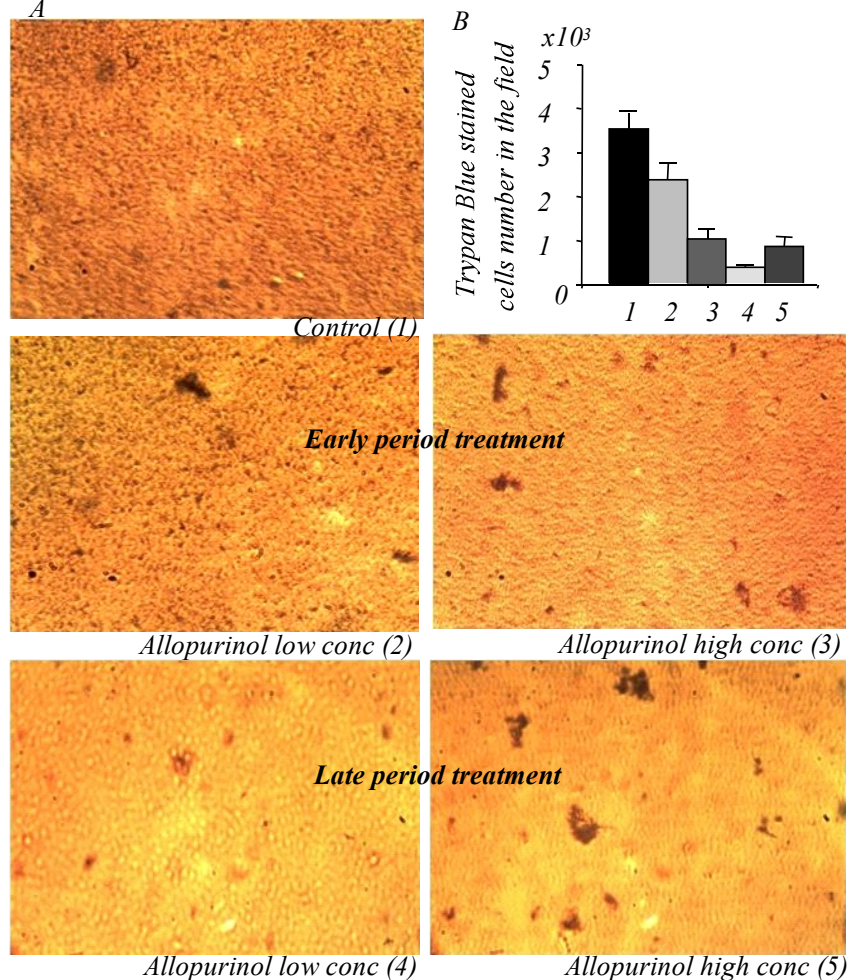

ith

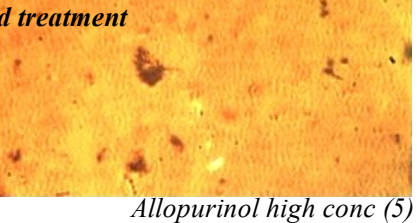

Fig. 3. The number of dead cells in the field, stained with the Trypan Blue $\mathrm{c}$ on $12^{\text {th }}$ day after seeding human embryonic neuronal cells. Magnification $60 \times 1.25 \times 20$. The pictures were taken on day $12^{\text {th }}(A)$. There were calculated results of the observation of 3 different fields from the plates for every group $(B)$. The first column represents the control group. The second column represents the cells treated with low, the thirdwith high concentrations of Allopurinol reflecting the conditions when the cells in the culture were receiving the Allopurinol from day $1^{\text {st }}$ to day $12^{\text {th }} .4^{\text {th }}$ and $5^{\text {th }}$ columns represent the group of the cells receiving the low and hight concentrations of Allopurinol from day $6^{\text {th }}$ to day $12^{\text {th }}$. The results were accepted as a statistically significant when $\mathrm{p}<0.05$

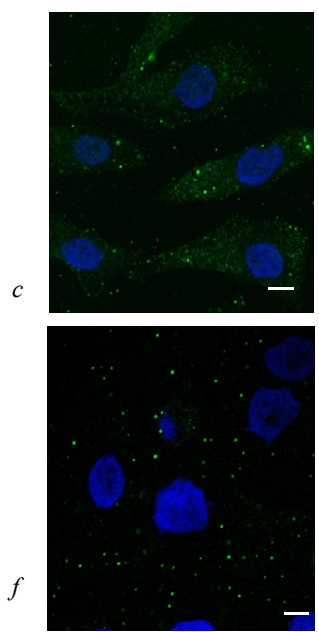

Fig..1. HEK293 cells were treated with rapamycin (b), LY294002 (c), 2-deoxyglucose (d), $\mathrm{CHX}(e)$ and sodium arsenite $(f)$ during $30 \mathrm{~min}$. Picture $a$ represent cells treated with DMSO. After treatment cells were fixed with $3.7 \%$ FA, and stained with anti-RCD-8 antibodies. As secondary were used FITC-conjugated antibodies. Cell nuclei were stained with Hoechst 33258. Magnification $\times 100$ 


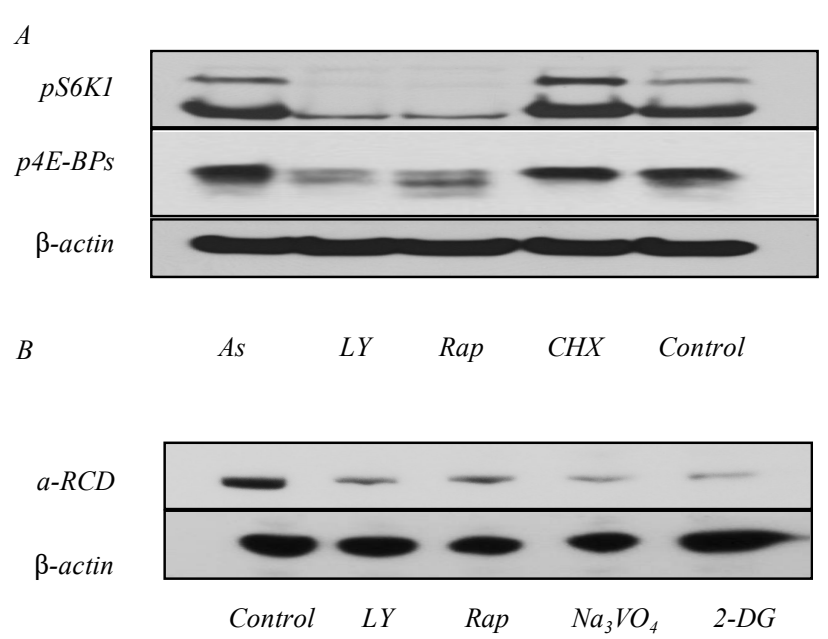

Fig. 2. $A$ - cycloheximide (CHX) treatment does not affect mTOR activity; $B$ - inhibition of PI3K/mTOR pathway reduces endogenous level of RCD-8. HEK293 were treated with arsenite (As), LY294002 (LY), rapamycin (Rap), $\mathrm{CHX}, \mathrm{Na}_{3} \mathrm{VO}_{4}$ and 2-deoxyglucose (2-DG) as described in Materials and methods. Then cells were lyzed in Laemmli buffer and analyzed in immunoblot using specific antibodies to RCD-8, pS6K, p4E-BPs and beta-actin

phorylation and slightly up-regulates 4E-BPs phosphorylation. Such effect may represent some compensatory mechanism after translation inhibition.

Next, to determine the dependence of PB assembly on the availability of growth factors, we starved HEK293 cells for $24 \mathrm{~h}$ and then stimulated with $20 \%$ fetal bovine serum for 0.5 or $3 \mathrm{~h}$. We observed reduction in the number of processing bodies upon starvation, while serum stimulation induced their formation (data not shown). This observation clearly indicates that the assembly of PBs is dependent on the presence of growth factors, which can activate major signal transduction pathways within cell.

We have also examined the level of endogenous RCD-8 in cells upon the above treatments. Unexpectedly, we found that the amount of RCD-8 protein was reduced in response to all tested inhibitors. The strongest effect was observed with 2-DG treatment (up to $50 \%$ reduction) (Fig. 2, B). To study it in more details, we carried out a time-course treatment with 2-DG, which included $15 \mathrm{~min}$ and $30 \mathrm{~min}$ time points. Significant decrease of RCD- 8 was observed after 15 min of treatment (Fig. 3, A). Introducing proteasomal inhibitor MG132 before 2-DG treatment (Fig. 3, $A$ ) we have found that the level of endogenous RCD-8 is regulated by proteasome-mediated degradation and the changes are observed even after 15 min upon treatment with 2DG (Fig. 3, $A$ ).

To study the half-life of RCD-8 in mammalian cells under normal conditions we carried out the experiment in the presence of $\mathrm{CHX}$, which prevents biosynthesis of novel proteins in cells. The results clearly indicated that RCD-8 is a quite stable protein with a half-life of more than $24 \mathrm{~h}$ (Fig. 3, B). So, decreasing of endogenous level of RCD-8 after treatment with different reagents could be explained by degradation of RCD-8 protein via proteasomal pathway. At the same time, the decreasing in endogenous RCD-8 does not correlate with observed increasing number of processing bodies within the cytoplasm after the treatment. The most reasonable explanation of observed effect could be as follow. Basically, the process of mRNA degradation occurs in PB, but due to the presence of decapping machinery and co-activators in the cytoplasm it can take place there as well but significantly slowly. Number of previous work $[4,6]$ described the dynamic shuttling of main PBs components between PBs and cytoplasm, and PBs represent sites with much more higher concentration of those proteins than in the cytoplasm. Therefore we assume we were able to detect RCD-8 only in PBs as intracellular sites with elevated local level of RCD-8 but not others where its content is much lower.

According to our data we speculate that PI3K/ mTOR pathway may affect the processes of PB assembly. As mentioned above, PBs represent cellular structures for storing the whole pool of non-translating mRNAs which can undergo either degradation or storage in those foci. At the same time there is no evidence about precise mechanism, which may regulate a fate of stored mRNAs. The appearance of huge PBs within cell can indicate a total increased level of mRNAs' decapping as well as accumulation of silenced mRNAs. Thus, we speculate that PI3K/mTOR signaling pathway can be one of possible mechanisms, which keep in balance the ratio between translated and non-translated mRNAs.

Conclusions. In summary, we showed that the regulation of processing body assembly might be mediated through the PI3K/mTOR signaling pathway. At the same time regulation of $\mathrm{PB}$ assembly in part occurs through the proteasomal degradation of PBs main component - scaffold protein RCD8. 

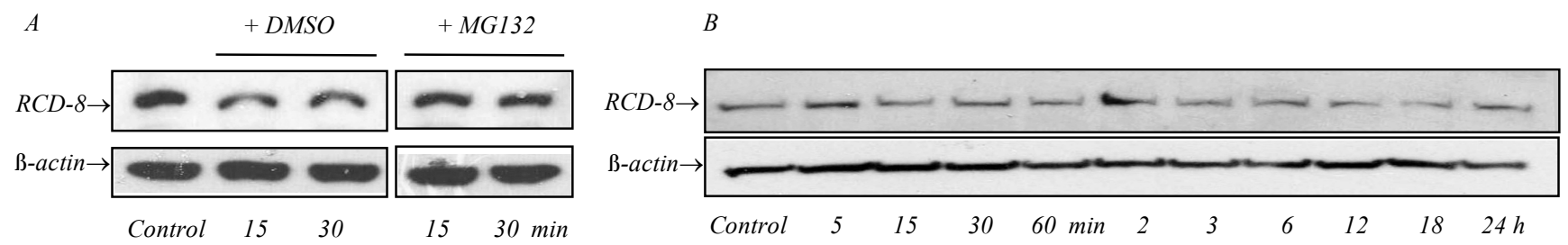

Fig. 3. 2-Deoxyglucose (2-DG) treatment affects endogenous level of RCD-8 protein: $A$ - HEK293 cells were pre-treated with MG132 or DMSO for $6 \mathrm{~h}$, then 2-DG was added for indicated time, after cells were lyzed in Laemmli buffer and total protein cell lysates were analyzed in immunoblot with indicated antibodies; $B$ - estimated period of RCD-8 half-life is more than $24 \mathrm{~h}$. HEK293 cells were treated with cycloheximide for indicated time points. Total protein lysates were prepared and analyzed as described for the above experiment

Acknowledgments. We thank Dr. V. Gorchev and Dr. S. Karakhim for help with confocal studies. This work was supported by the FEBS Collaborative Experimental Scholarships for Central and Eastern Europe.

\section{Д. О. Гудкова, Г. Г. Панасюк, І. О. Немазаний, В. В. Філоненко}

PI3K/mTOR-залежний сигнальний шлях як можливий регулятор утворення процесивних тілець.

\section{Резюме}

Meта. Дослідити роль PI3K/mTOR-залежного сигнального шиляу в регуляиії утворення прочесивних тілеиь. Методи. Використано методи імуноцитохімії та імуноблотингу. Результати. Показано, щзо обробка клітин спещифічними інгібіторами PI3K/mTORсигнального шляху призводить до змін у кількості та розмірах процесивних тілець та протеасомної деградаиії одного з основних білків процесивних тілець RCD-8. Висновки. Ми припустили, що PI3K/mTOR-сигнальний шлях регулює динаміку утворення процесивних тілець у клітині, забезпечуючи стабільність скефолдного білка процесивних тілець $R C D-8, i$, як наслідок, нормалізує метаболізм РНК у иілому.

Ключові слова: прочесивні тільия, імуноџитохімія, деградаиія мPHК, mTOR, сигнальні шляхи.

\section{Д. О. Гудкова, А. Г. Панасюк, И. А. Немазаный, В. В. Филоненко}

PI3K/mTOR-зависимый сигнальный путь как возможный регулятор образования процессивных телец

\section{Резюме}

Цель. Исследовать роль PI3K/mTOR-зависимого сигнального пути в регуляиии сборки прочессивных телец. Методы. Использованы методы иммуночитохимии и иммуноблоттинга. Резульmаты. Показано, что обработка клеток специифическими ингибиторами PI3K/mTOR-сигнального пути приводит к изменениям в количестве и размерах процессивных телеи в клетке, а также протеасомной деградации основного белка процессивных телеи RCD-8. Выводы. Mы предположили, что PI3K/mTOR-сигнальный путь регулирует динамику образования процессивных телеи, обеспечивая стабильность скеффолдного белка процессивных телец $R C D-8, u$, как следствие, нормализует метаболизм мРНК

Ключевые слова: прочессивные тельиа, иммуноцитохимия, деградаиия мРHК, mTOR, сигнальные пути.

\section{REFERENCES}

1. Averous J., Proud C. G. When translation meets transformation: the mTOR story // Oncogene.-2006.-25, N 48.-P. 6423-6435.

2. Sun S. Y., Rosenberg L. M., Wang X., Zhou Z., Yue P., Fu H., Khuri F. R. Activation of Akt and eIF4E survival pathways by rapamycin-mediated mammalian target of rapamycin inhibition // Cancer Res.-2005.-65, N 16.-P. 7052-7058.

3. Liu L., Li F., Cardelli J. A., Martin K. A., Blenis J., Huang S. Rapamycin inhibits cell motility by suppression of mTOR-mediated S6K1 and 4E-BP1 pathways // Oncogene.-2006.-25, N 53.-P. 7029-7040.

4. Kedersha N., Stoecklin G., Ayodele M., Yacono P., Lykke-Andersen J., Fritzler M. J., Scheuner D., Kaufman R. J., Golan D. $E$., Anderson P. Stress granules and processing bodies are dynamically linked sites of mRNP remodeling // J. Cell Biol.2005.-169, N 6.-P. 871-884.

5. Buchan J. R., Parker R. Eukaryotic stress granules: the ins and outs of translation // Mol. Cell.-2009.-36, N 6.-P. 932-941.

6. Erickson S. L., Lykke-Andersen J. Cytoplasmic mRNP granules at a glance // J. Cell Sci.-2011.-124, Pt 3.-P. 293-297.

7. Stinton L. M., Eystathioy T., Selak S., Chan E. K., Fritzler M. J. Autoantibodies to protein transport and messenger RNA processing pathways: endosomes, lysosomes, Golgi complex, proteasomes, assemblyosomes, exosomes, and GW bodies // Clin. Immunol.-2004.-110, N 1.-P. 30-44.

8. Parker R., Sheth U. P bodies and the control of mRNA translation and degradation // Mol. Cell.-2007.-25, N 5.-P. 635-646.

9. Garcia-Lozano J. R., Gonzalez-Escribano M. F., Wichmann I., Nunez-Roldan A. Cytoplasmic detection of a novel protein containing a nuclear localization sequence by human autoantibodies // Clin. Exp. Immunol.-1997.-107, N 3.-P. 501-506.

10. Yu J. H., Yang W. H., Gulick T., Bloch K. D., Bloch D. B. Ge-1 is a central component of the mammalian cytoplasmic mRNA processing body // RNA.-2005.-11, N 12.-P. 1795-1802.

11. Gudkova D. O., Panasyuk G. G., Nemazanyy I. O., Filonenko V. $V$. Novel antibodies against RCD-8 as a tool to study processing bodies // Biopolym. Cell.-2010.-26, N 6.-P. 512-516.

12. Kedersha N., Anderson P. Mammalian stress granules and processing bodies // Methods Enzymol.-2007.-431.-P. 61-81.

13. Balynska O. V., Baklaushev V. P., Areshkov P. O., Avdieiev S. S., Boyko O. I., Chekhonin V. P., Kavsan V. M. Characterization of new cell line stably expressing CHI3L1 oncogene // Biopolym. Cell.-2011.-27, N 4.-P. 285-290.

14. Yang Q., Inoki K., Kim E., Guan K. L. TSC1/TSC2 and Rheb have different effects on TORC1 and TORC2 activity // Proc. Natl Acad. Sci. USA.-2006.-103, N 18.-P. 6811-6816. 